DOI: $10.17580 /$ cisisr.2020.02.09

\title{
EFFECT OF LASER TREATMENT MODES ON METAL SURFACE MARKING COLOR
}

\author{
S. M. Gorbatyuk ${ }^{1}$, I. G. Morozova ${ }^{1}$, M. G.Naumova ${ }^{1}$, N. A. Chichenev ${ }^{1}$ \\ ${ }^{1}$ National University of Science and Technology "MISiS"
}

E-mail: chich38@mail.ru

\begin{tabular}{|c|c|}
\hline AUTHOR'S INFO & A B ST RACT \\
\hline $\begin{array}{l}\text { S. M. Gorbatyuk, Dr. Eng., Prof., } \\
\text { Head of Dept. of Engineering } \\
\text { of Technological Equipment; } \\
\text { I. G. Morozova, Cand. Eng., } \\
\text { Assistant Prof., Dept. of Engineering } \\
\text { of Technological Equipment; } \\
\text { M. G. Naumova, Senior Researcher, } \\
\text { Dept. of Engineering of Technologi- } \\
\text { cal Equipment; } \\
\text { N. A. Chichenev, Dr. Eng., Prof., } \\
\text { Dept. of Engineering of Technologi- } \\
\text { cal Equipment }\end{array}$ & $\begin{array}{l}\text { The laser beam marking process is considered to be a subject to important scientific research. In this } \\
\text { area, there are insufficiently studied problems and concepts requiring their experimental validation and } \\
\text { determining the solutions. Upon laser action, the effect of metal surface coloration can be caused by } \\
\text { different processes. The most probable is formation of thin oxidic films, although formation of the } \\
\text { other compounds is not unlikely as well [1-2]. Under actual values of luminous flux density, however, } \\
\text { scanning with laser beam results in occurrence of regular surface roughness. Therefore, the analysis } \\
\text { of diffraction effect impact on the image color is also necessary [3-4]. The color images on the metal } \\
\text { surface were assessed based on range of colors RAL "Reich Ausschluß für Lieferbedingungen". In this } \\
\text { system, the color space is divided to ranges with identification of each color by its unique index number. } \\
\text { When doing research of the metal surface composite regular relief [5] obtained using laser marker, the } \\
\text { depth of microroughnesses in differently colored samples was determined. The was performed using } \\
\text { non-contact VICWU profilometer. Due to the method of measurement technological specificity, this } \\
\text { equipment does not have destructive effect on the object under study. }\end{array}$ \\
\hline $\begin{array}{l}\text { Key words: } \\
\text { laser beam marking, metal surface, surface } \\
\text { composite regular relief, depth of micro- } \\
\text { roughnesses, roughness parameters, non- } \\
\text { contact profilometer, surface profilogram. }\end{array}$ & $\begin{array}{l}\text { The roughness values }\left(R_{\mathrm{z}} \text { and } R_{\mathrm{a}}\right) \text { of the surfaces under study were measured based on acceptably small } \\
\text { areas, thereat the base lines were selected in such way that to consider the surface waviness effect on the } \\
\text { roughness values } R_{\mathrm{z}} \text { and } R_{\mathrm{a}}[6] \text {. } \\
\text { The research results demonstrated that change of surface roughness values } R_{\mathrm{a}} \text { and } R_{\mathrm{z}} \text { by } 1.5 \text { times (ow- } \\
\text { ing to change of the surface laser treatment mode), changes the specimen metal surface coloration } \\
\text { drastically. }\end{array}$ \\
\hline
\end{tabular}

\section{Introduction}

Owing to actively carried out research in the area of laser beam marking, it acquired the status of competitive, promising and dynamically developing technological trend. The laser beam marking is one of the most precision and reliable modern method for counterfeit protection of products and application of the other required information on the output products [7-9].

Using high-quality laser beam marking, each product unit produced by the enterprise is kept strict record [10-12]. Herewith, the control of products is kept not only inside the enterprise but after its selling as well. The laser beam marking application on the metal products is extremely important and is necessary in such industries as instrumentation design, aircraft industry, automotive industry, when manufacturing various tools, etc. [13-15]. Herewith, it is a very important fact that the image in applied on the metal surface with high precision and with no mechanical effect on the product [16]. Due to reaching the laser beam diameter diffraction limit practically, an option for treated area reduction appeared. During various information application on the produced part, you manage to avoid the surface significant deformation [16, 17].

The color laser beam marking of the metal surfaces expands the laser beam marking application opportunities substantially. Such "color" version of the laser beam marking and engraving can be useful, in particular, in industrial production (application of color logos on the output products to exclude possibility for counterfeit and damage), in advertising business (promotional mer- chandise, advertising cards, instrument panels), jewellery making, decorative and applied arts, etc. The laser impulse action allows for forming the image on the metal surfaces in full colors [18].

Sometimes, due to process specifics, the laser beam marking of of mass production items must be apprehensible for maintenance personnel without the instrumentation. For example, the in-line assembly is performed in a number of industries within the strict space and time framework and the issue on one and the other part correct application requires very fast response. In such cases the color laser beam marking is indispensable.

The only restriction for wider method application is inadequate predictability of obtained color as a result of irradiation. The factors of impact on the process of obtaining the color image on the metal surfaces are explored relatively a little and narrow specific, and, therefore, they require further research for identification, systematization and determination of interaction for these factors. The most of modern research on this issue is concentrated on experimental study of well-defined conditions for obtaining one or the other color on the surface of steels and alloys [19].

\section{Task setting}

Upon laser action on the metal surfaces, the composite periodic relief is formed. As a result of research, it was identified that the surface represents the "scores" obtained as a result of the laser beam passing on the metal surface during "coloration" of the spot under its action. 
At the same time, the build-ups on the spot of action are formed on the metal surface. The build-ups are developed as a result of metal boiling, thus, forming the surface composite relief during laser irradiation [20]. It can speak to the fact that visually perceptible coloration relates not only to the occurrence of discoloration and interference in thin films, but it may also be the result of diffraction, i.e. joint occurrence of several processes in parallel. In this connection, the process of color for-

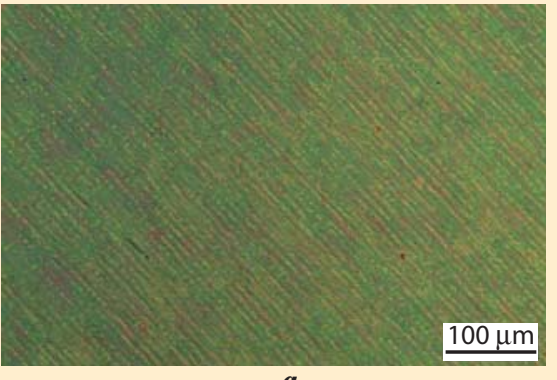

$\boldsymbol{a}$

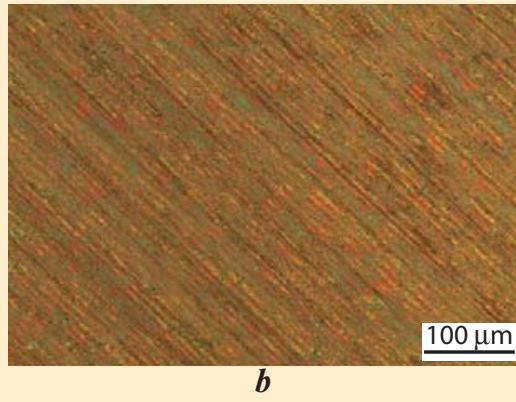

Fig. 1. Screenshots obtained using the optical microscope at $\times 200$ magnification: $a$ - "green fern" (Group RAL 6025) sample; $b$ - "redand-orange” (Group RAL 2001) sample mation during laser beam marking is quite complicated, which assumes necessary to conduct further research [21].

Work objective: research on effect of factors capable to cause the diffraction effect on the image color during laser beam marking.

\section{Methods and materials}

In the course of our research the metal materials with different thermal and physical characteristics were selected: steel 12Kh18N10T (12X18H10T); brass L63 (Л63); steel 08 with the coating applied by galvanic chromizing, etc. In this paper, the results for stainless steel only are given, as they can be compared to the data on this steel marking earlier obtained by the other researchers.

The stainless steel surface areas having contrast colors as a result of laser beam marking with different parameters were used as the objects under study. For applying color image on the pilot metal plates, the pulse optical fiber laser Version YLP-Fu HansLaserMars Model 20J with the following performance data were used: wave length $1064 \mathrm{~nm}$; rated output power $-20 \mathrm{~W}$; duration of pulse under frequency $40 \mathrm{kHz}-120 \mathrm{~ns}$; pulse repetition rate $20-100 \mathrm{kHz}$; linear beam displacement $-3 \mathrm{~mm}$; laser spot diameter in focus $-30 \mu \mathrm{m}$. The used laser engraver operates jointly with the software MarkingSoftware 6.0, which provides an option for setting the required laser treatment mode: geometry parameters, length and width of marked object, laser irradiation parameters, scanning speed, laser beam travel speed, etc.

For assessment of obtained color image, selection of estimation range of colors RAL was made. RAL - one of the most wide-spread and demanded systems for this period. The standard is divided to ranges and any color tone is marked with the RAL prefix and the index number.

In our research, for obtaining certain contrast RAL groups, the laser irradiation parameters were changed: pulse repetition rate, laser irradiation power, laser beam travel speed, etc. Herewith, we obtained various coloration colors: green fern (Group RAL 6025); red-and-orange (Group RAL 2001); black-and-green (Group RAL 6012); golden-and-yellow (Group RAL 1004), etc.

For conducting research, the samples (Fig. 1) from the Group of green $(a)$ and red $(b)$ RAL color range were se-
lected.Visual perception of colors matched with the color image captured with the microscope AxioObserver D1m at $\times 200$ magnification.

Note that the research made with use of the optical microscope is designed only for assessment of the obtained color images using the range of colors. In Fig.1 you can see how the microrelief produces an effect on the surface coloration.

In the paper, there was no task to obtain direct evidences of the initial material chemical and phase composition effect. The other issue was under study - surface roughness effect on coloration upon laser irradiation action. This issue requires detailed consideration, and the authors plan to do the relative experimental research, for which the corresponding procedures for their conduct were developed. Unfortunately, at present, it is far too difficult to implement these plans due to coronavirus pandemic. The preliminary research using the X-ray diffractometer demonstrated that the oxide films on steel $12 \mathrm{Kh} 18 \mathrm{~N} 10 \mathrm{~T}$ surface occurring, as a result of laser treatment, contain $\mathrm{Fe}_{3} \mathrm{O}_{4}$ and $\mathrm{NiO}_{4}$ based on $\mathrm{Cr}$ and Ni solutions.

For studied surfaces, the coloration was obtained using the laser irradiation with the parameters given in Table 1. When doing research of the metal surface composite regular relief obtained using laser marker, the depth of microroughnesses in differently colored samples was determined. The work was performed using the non-contact profilometer and analysing the image of the surface levels formed by the device from a set of interference images. Due to the method of measurement technological

\begin{tabular}{|l|c|c|}
\hline \multicolumn{2}{|l}{$\begin{array}{l}\text { Table 1. Laser irradiation parameters for the samples selected } \\
\text { for measurement of roughness parameters }\end{array}$} \\
\hline \multirow{2}{*}{\begin{tabular}{c} 
Laser irradiation parameters \\
\cline { 2 - 3 }
\end{tabular}} & $\begin{array}{c}\text { Group RAL 3020, } \\
\text { intense red }\end{array}$ & $\begin{array}{c}\text { Group RAL 6002, } \\
\text { green leaf }\end{array}$ \\
\hline$f-$ pulse repetition rate, $\mathrm{kHz}$ & 50 & 50 \\
\hline $\begin{array}{l}P \text { - laser irradiation power, } \\
\text { medium }\end{array}$ & 12 & 12 \\
\hline $\begin{array}{l}\text { L- distance between beam } \\
\text { passes, mm }\end{array}$ & 0.005 & 0.005 \\
\hline$V-$ beam travel speed, $\mathrm{mm} / \mathrm{s}$ & 400 & 400 \\
\hline$N-$ number of passes. & 1 & 2 \\
\hline
\end{tabular}


specificity, this equipment does not have destructive effect on the object under study..

\section{Obtained results and their analysis}

Upon laser action, the effect of metal surface coloration can be caused by different processes. The most probable is formation of thin oxidic films [22], although formation of the other compounds is not unlikely as well. Under actual values of luminous flux density, however, scanning with laser beam results in occurrence of regular surface roughness. Therefore, the analysis of diffraction effect impact on the image color is also necessary [23-24].

The authors used the term "diffraction" to describe the phenomenon occurring when the light wave runs upon an obstacle. The results of the experimental research for effect of the marked metal surface regular roughness parameters on its coloration, following which the effect of the surface microgeometry vertical parameters determining visual perception of the color image obtained upon metal surface laser beam marking was identified, are given below.

The profilogram given in Fig. 2, obtained by noncontact method, differs from the profilogram obtained on the contact devices fundamentally. The non-contact profilometer records the research area, determines the surface roughness parameters and represents the image of the area under research in accordance with the range of color (not shown in the Figure) and the roughness averaged parameters using the computer and the printer. The research area was also was also recorded using the metallographic microscope.

When measuring the samples, two parameters of the surface under research roughness were obtained: $R a$ and $R z$ :

$R a$ - arithmetic mean from the absolute values of the profile deviations within the base length limits, $\mu \mathrm{m}$;

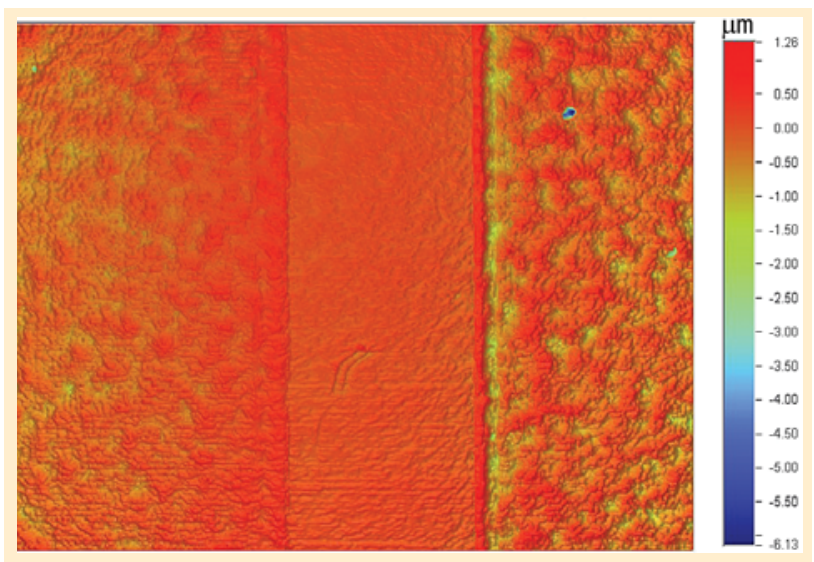

Fig. 2. Two-dimensional profilogram of the area under research

Table 2. Results of roughness measurement for differently colored samples

\begin{tabular}{|l|c|c|}
\hline \multirow{2}{*}{ Group and sample color } & \multicolumn{2}{|c|}{ Surface roughness parameter, $\mu \mathrm{m}$} \\
\cline { 2 - 3 } & $R_{\mathrm{a}}$ & $R_{\mathrm{z}}$ \\
\hline Group RAL 6002, green leaf & $0.261 \pm 0.001$ & $3.063 \pm 0.393$ \\
\hline Group RAL 3020, intense red & $0.167 \pm 0.002$ & $1.870 \pm 0.247$ \\
\hline
\end{tabular}

$R z$ - total of mean absolute values of heights for five largest profile peaks and of five largest profile valleys within the base length limits, $\mu \mathrm{m}$.

The obtained roughness measurements for samples are given in Table 2 .

The roughness values ( $R z$ and $R a$ ) of the surfaces under study were measured based on acceptably small areas, thereat the base lines were selected in such way that to consider the surface waviness effect on the roughness values $R z$ and $R a$.

It was demonstrated that increase of the height of irregularities by 1.5 times (due to double beam pass with other equal conditions), changes the surface color coloration from red to green drastically. Thus, as a result of research, the new experimental data on the surface microrelief effect on its coloration during laser action were obtained. This confirms an assumption set forth in the paper [6] as to the fact that visual coloration relates not only to the occurrence of discoloration and interference in thin films, but it may also be the result of diffraction, i.e. joint occurrence of several processes in parallel.

\section{Conclusion}

Color laser beam marking is a promising area in enhancing counterfeit protection in different production facilities [24-32]. Such marking of surface for metal products meets the requirements of the applied image quality and durability. This work has confirmed the opinion of many domestic and foreign specialists as to the fact that wide range of factors has an impact on formation of color spectrum on the metal surface upon laser action. The research has demonstrated the effect of the marked metal surface regular roughness parameters on its coloration. The effect of the surface microgeometry vertical parameters, as one of the factors determining visual perception of the color image obtained upon metal surface laser beam marking, was identified. Change in regular relief irregularities depth on the stainless steel surface by 1.5 times changes the surface coloration color completely; herewith, the roughness parameters changed within the range of $R_{\mathrm{a}}=0.261-0.167 \mu \mathrm{m}$ and $R_{\mathrm{z}}=3.063-1.870 \mu \mathrm{m}$.

\section{REFERENCES}

1. Kuzmina T. A., Masyagin V. S. Laser Engraving as Modern Marking Method. Collection of papers of XVII international Scientific Practical Conference "Scientific Community of XXI Century Students. ENGINEERING SCIENCES” (Russia, Novosibirsk, February 18, 2014). p. 6.

2. Gornyi S. G., Yudin K. V. Laser Beam Marking Industry. Metal Treatment Dimensional Machining Technologies. 2003. No. 6(18), pp. 21-23.

3. Grigoryants A. G., Shiganov I. N., Misyurov A. I. Laser Treatment Processes. M.: MGTU imeni N.E. Baumana. 2006. p. 664.

4. Veiko V. P., Gornyi S. G., Odintsova G. V., Patrov M. I., Yudin K. V. Formation of Multicolor Image on Metal Surfaces Upon Its Laser Oxidation. Izvestiya VUZov. Priborostroenie. 2011. Vol. 54. No. 2. pp. 47-51

5. Kuznetsov P. M., Fedorov V. A. Features of Relief Formation on Metal Surfaces in the Laser Spot. Vestnik Tambovskogo 
gosudarstvennogo universiteta imeni G. R. Derzhavina. 2015. Vol. 20, Iss. 4. pp. 872-877.

6. Antonov D. N., Burtsev A. A., Butkovskii O. Ya. Metal Surface Coloration Under Laser Pulse Irradiation. Journal of Technical Physics. 2014. Vol. 84, Iss. 10. pp. 83-86.

7. Eronko S. P., Kuklev A. V., Tkachev M. Y., Tinyakov V. V., Mechik S. V. Improvement in the Reliability of Mechanical Flux Feed Systems for Continuous Slab-Casting Machine Molds. Metallurgist. 2019. Vol. 62 (9-10). pp. 892-899. DOI: 10.1007/s11015-019-00742-w.

8. Eronko S. P., Tkachev M. Y., Oshovskaya E. V. Hydraulic simulation of the replacement of submerged nozzles in slab continuous casters. Russian Metallurgy (Metals). 2017. Vol. 6. pp. 441-446. DOI: 10.1134/S0036029517060088.

9. Eronko S. P., Danilov V. L., Kuklev A. V., Tkachev M. Y., Tinyakov V. V., Mechik S. V. Experience of Design and Industrial Application of Systems for the Driven Feed of Slag-Forming Mixtures into the Crystallizers of Slab CCM. Metallurgist. 2020. Vol. 64 (3-4). pp. 214-222. DOI: 10.1007/s11015-02000986-x.

10. Eronko S. P., Danilov V. L., Tkachev M. Y., Tinyakov V. V., Ponomareva E. A. Model Studies and Modernization of a Manipulator for Tapping Spout Replacement in Continuous Steel Casting. Metallurgist. 2020. Vol. 64 (3-4). pp. 301-308. DOI: 10.1007/s11015-020-00996-9.

11. Kalinsky O. I., Kruzhkova G. V., Aleksakhin A. V., Molchanov G. A. Selection of the Optimal Strategy for the Supply of Raw Materials Based on Game Theory. Smart Innovation, Systems and Technologies, 2019. Vol. 139. pp. 577-583. DOI: 10.1007/978-3-030-18553-4_70.

12. Naumova M., Basyrov I., Aliev K. Reengineering of the ore preparation production process in the context of "Almalyk MMC” JSC. MATEC Web of Conferences. 2018. Vol. 224, Article No. 01030. DOI: 10.1051/matecconf/201822401030.

13. Eronko S. P., Oshovskaya E. V., Tkachev M. Y. Fast replacement of submersible tundish nozzles in a continuous slab-casting machine. Steel in Translation. 2016. Vol. 46 (1). pp. 33-38. DOI: $10.3103 /$ S0967091216010034.

14. Dobrzycki P., Ivannikov A. L., Rybak J., Shkodkina V. O., Tyulyaeva Y. The impact of Rapid Impulse Compaction (RIC) of large non-cohesive material deposits on the surrounding area. IOP Conference Series: Earth and Environmental Science. 2019. Vol. 362 (1). article No. 012132. DOI: 10.1088/17551315/362/1/012132.

15. Snitko S. A., Yakovchenko A. V., Sotnikov A. L. Influence of wheel billet stamping schemes on power modes of forming press operation and on wear of the deformation tool. Izvestiya vuzov. Chernaya metallurgiya. 2018. Vol. 61 (5). pp. 385-392. DOI: 10.17073/0368-0797-2018-5-385-392.

16. Ganzulenko O. Yu., Larionova E. V., Petkova A. P. Laser Beam Marking Technology for Stock-Produced Products Made of Metal and Polymer Materials for Their Counterfeit Protection and Identification. "NAUKOVEDENIE" Internet magazine. 2013. No. 5 (18). Available at: http://naukovedenie. $\mathrm{ru} / \mathrm{PDF} / 72 \operatorname{tvn} 513 . \mathrm{pdf}$

17. Chichenev N. A., Gorbatyuk S. M., Naumova M. G., Morozova I. G. Using the similarity theory for description of laser hardening processes. CIS Iron and Steel Review. 2020. Vol. 19. pp. 44-47. DOI: 10.17580/cisisr.2020.01.09.

18. Larionova E. V. Development of Technology for Obtaining Displayed Multicolor Images on Metal Surfaces Using Lasers: Thesis for PhD in Eng.: 17.00.06 - Industrial Aesthetics and Design. GOU VPO "SZTU” (State educational institution of higher vocational education, "North-West Extramural Technical University”). 2010, p. 168.

19. Odintsova G. V. Research and Development of Technology for Color Laser Beam Marking Metals by Local Oxidation Method: Author's Abstract Thesis for PhD in Eng.: 05.27.03Quantum Electronics. St. Petersburg National Research University of Information Technologies, Mechanics and Optics (ITMO). 2014. p. 20.

20. Vasilyev O. S. Laser Formation of Metal Surface Microgeometry Using Nanosecond Duration Pulses: Thesis for Ph.D. in Engineering Sciences: 05.11.14. FGAOU VO St. Petersburg National Research University of Information Technologies, Mechanics and Optics. 2017. p. 173.

21. Ganzulenko O. Yu., Petkova A. P. Selection of Steel Composition for Obtaining Full Color Spectrum Images on Product Surfaces Upon Pulse Laser Irradiation. Zapiski Gornogo institute. Sovremennye problem mashinostroeniya, materialovedeniya i priborostroeniya gornogo, metallurgicheskogo i neftepererabatyvayushchego proizvodstv. 2014. Vol. 209. pp. 216-219.

22. Karlov N. V. Kirichenko N. A., Lukyanchuk B.S. Laser Thermochemistry. Fundamentals and Application. M.: Nauka. $1992.296 \mathrm{p}$.

23. Shtokkum V., Klain Z. Color Laser Beam Marking. Patent No. 2356741 Russian Federation, B41M5/40. Patent Owner MERK Patent GMBKh (DE). Application: 2006120080/12 dated 15.10.2004.

24. Valiulin A. G., Gornyi S. G., Grechko Yu. B., Patrov M. V., Yudin K. V., Yurevich V. A. Laser Beam Marking of Materials. Fotonika. 2007. No. 3. pp. 16-22.

25. Artiukh V., Mazur V., Pokrovskaya E. Influence of Strip Bite Time in Work Rolls Gap on Dynamic Loads in Strip Rolling Stands. MATEC Web of Conferences. 2016. 86. Article No. 01030. DOI: 10.1051/matecconf/20168601030.

26. Shapoval A. N., Shapoval A. A. Development of the unit for multi-stage vibration drawing of metal products. Non-Ferrous Metals. 2002. No. 4. pp. 77-82.

27. Markov O. E., Gerasimenko O. V., Shapoval A. A., Abdulov O. R., Zhytnikov R. U. Computerized simulation of shortened ingots with a controlled crystallization for manufacturing of high-quality forgings. International Journal of Advanced Manufacturing Technology. 2019. Vol. 103 (5-8). pp. 30573065. DOI: 10.1007/s00170-019-03749-4.

28. Dragobetskii V., Zagirnyak M., Naumova O., Shlyk S., Shapoval A. Method for determination of technological durability of plastically deformed sheet parts of vehicles. International Journal of Engineering and Technology (UAE). 2018. Vol. 7(4). pp. 92-99. DOI: 10.14419/ijet.v7i4.3.19558.

29. Sanjay M. R., Arpitha G. R., Senthamaraikannan P., Kathiresan M., Saibalaji M. A., Yogesha B. The Hybrid Effect of Jute/Kenaf/E-Glass Woven Fabric Epoxy Composites for Medium Load Applications: Impact, Inter-Laminar Strength, and Failure Surface Characterization. Journal of Natural Fibers. 2019. Vol. 16 (4). pp. 600-612. DOI: 10.1080/15440478.2018.1431828.

30. Bharath K. N., Sanjay M. R., Jawaid M., Harisha Basavarajappa S., Siengchin S. Effect of stacking sequence on properties of coconut leaf sheath/jute/E-glass reinforced phenol formaldehyde hybrid composites. Journal of Industrial Textiles. 2019. Vol. 49 (1). pp. 3-32. DOI: 10.1177/1528083718769926.

31. Gupta R. K., Pant B., Agarwala V., Agarwala R. C., Sinha P. P. Effect of Pressure and Temperature on Phase Transformation and Properties of Titanium Aluminide Obtained through Reaction Synthesis. Journal of Materials Science and Technology. 2010. Vol. 26 (8). pp. 693-704. DOI: 10.1016/S10050302(10)60109-0.

32. Gupta R. K., Pant B., Kumar V., Agarwala V., Sinha P. P. Deformation behavior of $\gamma+\alpha 2$ Ti aluminide processed through reaction synthesis. Materials Science and Engineering A. 2013. Vol. 559. pp. 49-67. DOI: 10.1016/j.msea.2012.08.016. 